\title{
Yield of green beans subjected to continuous and pulse drip irrigation with saline water
}

\author{
Willian F. de Almeida ${ }^{1}$, Vital P. da S. Paz ${ }^{1}$, Ana P. C. de Jesus², \\ Jucicléia S. da Silva ${ }^{1}$, Karoline S. Gonçalves ${ }^{1} \&$ Andressa S. de Oliveira $^{2}$
}

${ }^{1}$ Universidade Federal do Recôncavo da Bahia/Programa de Pós-Graduação em Engenharia Agrícola/Núcleo de Engenharia de Água e Solo. Cruz das Almas, BA. E-mail: wifatec@yahoo.com.br (Corresponding author) - ORCID: 0000-0001-7394-2865; vitalpaz@ufrb.edu.br - ORCID: 0000-0002-8034668X; jucicleiass@gmail.com - ORCID: 0000-0003-3409-0326; karolinesg@yahoo.com.br - ORCID: 0000-0002-1124-9309

${ }^{2}$ Universidade Federal do Recôncavo da Bahia/Centro de Ciências Agrárias, Ambientais e Biológicas/Núcleo de Engenharia de Água e Solo. Cruz das Almas, BA. E-mail: annapaula.agronomia@gmail.com - ORCID: 0000-0001-7001-4131; andressaufrb@gmal.com - ORCID: 0000-0002-0246-6715

\section{Key words:}

Phaseolus vulgaris

pot

greenhouse

water use efficiency

\begin{abstract}
A B S T R A C T
In view of the imminent need for efficient water use and the search for adequate management techniques to reduce the effect of salinity on plants, a study was conducted to evaluate the effect of continuous and pulses drip irrigation with saline water on green bean yield and water use efficiency. The experiment was conducted in a greenhouse, in a completely randomized design, with treatments distributed in a $2 \times 5$ factorial arrangement. The first factor was type of drip irrigation, i.e., continuous or pulse, while the second factor was the levels of water salinity (electrical conductivity of $0.3,1.5,2.5,3.5$ and $4.5 \mathrm{dS} \mathrm{m}^{-1}$ ), with five replicates, and two plants per replicate, totaling 50 experimental units. The following variables were analysed: production of pods per pot, water use efficiency and the electrical conductivity of the soil saturation extract. According to the results, significant effect of the interaction and decreasing linear fits in response to salinity occurred for all variables studied. It was possible to note that pulse drip irrigation reduced the negative effects of irrigation water salinity on green bean yield and increased water use efficiency.
\end{abstract}

\section{Palavras-chave:}

Phaseolus vulgaris

vaso

ambiente protegido

eficiência do uso da água

\section{Rendimento do feijão-vagem submetido ao gotejamento contínuo e por pulsos com água salina}

\begin{abstract}
R E S U M O
Em face à iminente necessidade do uso eficiente da água e a busca por técnicas de manejo adequado que possibilite reduzir o efeito da salinidade nas plantas, foi realizado um estudo para avaliar o efeito da aplicação de água salina através do gotejamento contínuo e por pulsos sobre a produção e a eficiência do uso da água na cultura do feijão-vagem. $\mathrm{O}$ experimento foi conduzido em casa-de-vegetação, com delineamento inteiramente casualizado, com tratamentos distribuídos em esquema fatorial $2 \times 5$, sendo o primeiro fator a aplicação por gotejamento contínuo e por pulsos; e o segundo, os níveis de salinidade da água (condutividade elétrica de 0,$3 ; 1,5 ; 2,5 ; 3,5$ e 4,5 dS m $\mathrm{m}^{-1}$ ), com 5 repetições e duas plantas por repetição, totalizando 50 unidades experimentais. Analisaram-se as seguintes variáveis: produção de frutos por vaso, eficiência do uso da água e a condutividade elétrica do extrato de saturação do solo. Verificou-se efeito significativo da interação e ajuste linear decrescente da salinidade sobre todas as variáveis analisadas. Foi possível constatar que o gotejamento por pulsos reduziu os efeitos negativos da salinidade da água de irrigação no rendimento do feijão-vagem e aumentou a eficiência do uso da água.
\end{abstract}




\section{INTRODUCTION}

Water availability for agricultural use has been gradually reduced in both quantity and quality, making necessary the alternative use of lower-quality water. In semi-arid regions, it is common to use water with high salt contents in agriculture (Oliveira et al., 2011).

Green bean is one of the main vegetables cultivated in Brazil, mainly by small farmers. This crop is widely cultivated in greenhouses, which allows harvests in off-season periods, thus promoting higher profitability to the producer (Bottega et al., 2013; Almeida et al., 2014). It is a salt-sensitive crop whose yield and quality of pods decrease with the increment in irrigation water salinity (Osman \& Salim, 2016).

Pulse drip irrigation consists of a short period of watering followed by a pause and another short period of watering, and this cycle repeats until all the required water depth is applied. This technique has been studied for several crops in different regions of the world, such as for soybean in Egypt (Eid et al., 2013), tomato in Saudi Arabia (Elnesr et al., 2015) and potato in Egypt (Abdelraouf et al., 2012). These studies have found positive effects on the increase of yield, improvement of product quality, savings in water use, among others. Nevertheless, studies on the effects of pulse drip irrigation using saline water on crop production are still scarce.

Therefore, this study aimed to evaluate the effects of applying water with different salinity levels through continuous and pulse drip irrigation on green bean production.

\section{Material AND Methods}

The experiment was carried out from March 18 to June 4, 2016 in the Experimental Area of the Graduate Program in Agricultural Engineering of the Federal University of Recôncavo of Bahia, located in the municipality of Cruz das Almas, BA, Brazil (12³9’ 32” S; 3905’ 09” W; 220 m). Based on Köppen's classification, the climate of the region is Aw (hot and humid tropical, with rainy and dry season). Mean annual rainfall according to historical data (1980 to 2012 ) is $1,051 \mathrm{~mm}$, with mean relative air humidity of $80 \%$ and mean temperature of $24.5^{\circ} \mathrm{C}$ (Lima et al., 2015).

The experiment was conducted in 7-m-wide, 28-m-long arched greenhouse, with $3 \mathrm{~m}$ ceiling height, black screen on the sides and covered by 150 - $\mu \mathrm{m}$-thick polyethylene film.

Inside the greenhouse, mean temperatures varied from 21.8 to $34.8^{\circ} \mathrm{C}$. According to Nadal et al. (1986), green bean is a vegetable that adapts well to mild or hot climates with temperatures between 18 and $30^{\circ} \mathrm{C}$ and is hampered by temperatures above $35^{\circ} \mathrm{C}$.

The statistical design adopted was completely randomized, with ten treatments distributed in a $2 \times 5$ factorial scheme, in which the first factor corresponded to two types of drip irrigation (continuous and pulse) and the second one to five levels of electrical conductivity $\left(0.3 ; 1.5 ; 2.5 ; 3.5\right.$ and $\left.4.5 \mathrm{dS} \mathrm{m}^{-1}\right)$. The experimental plots were spaced by $1.00 \times 0.60 \mathrm{~m}$. Plastic pots with volume of $21 \mathrm{dm}^{3}$ were filled with a thin layer of crushed stone $( \pm 2 \mathrm{~cm})$, covering the bottom, followed by a screen and soil. Each pot received $27 \mathrm{~kg}$ of dried soil and its mean bulk density in the pots was $1.37 \mathrm{~kg} \mathrm{dm}^{-3}$.

The soil used, classified as dystrocohesive Yellow Latosol with medium texture and low fertility, was collected in the 0-0.20 m layer at the UFRB campus. Soil chemical analyses were previously conducted (EMBRAPA, 1997), and the results are presented in Table 1 .

As recommended by Trani et al. (2015), liming was carried out to increase base saturation to $80 \%$, applying $84 \mathrm{~g} \mathrm{pot}^{-1}$ of dolomitic limestone. Fertilization at planting was applied by incorporating to the soil $300 \mathrm{~g} \mathrm{pot}^{-1}$ of organic compost, $2.4 \mathrm{~g} \mathrm{pot}^{-1}$ of $\mathrm{N}$; 19.2 g pot $^{-1}$ of $\mathrm{P}_{2} \mathrm{O}_{5} ; 7.2$ g pot $^{-1}$ of $\mathrm{K}_{2} \mathrm{O} ; 0.18 \mathrm{~g} \mathrm{pot}^{-1}$ of $\mathrm{Zn}$; 0.06 g pot $^{-1}$ of $\mathrm{B}$ and $0.12 \mathrm{~kg} \mathrm{pot}^{-1}$ of $\mathrm{Cu}$. N, $\mathrm{P}$ and $\mathrm{K}$ doses were applied in the form of monoammonium phosphate (MAP) and potassium nitrate, whereas $\mathrm{Zn}, \mathrm{B}$ and $\mathrm{Cu}$ doses were applied in the form of zinc sulfate, boric acid and copper sulfate. Two top-dressing fertilizations were applied, at 20 and 40 days after emergence, by splitting the amounts of $7.2 \mathrm{~g} \mathrm{pot}^{-1} \mathrm{of} \mathrm{N}, 2.4 \mathrm{~g} \mathrm{pot}^{-1}$ of $\mathrm{P}_{2} \mathrm{O}_{5}$ and 3.6 g pot $^{-1}$ of $\mathrm{K}_{2} \mathrm{O}$ (Trani et al., 2015).

The crop used in the experiment was green bean (Phaseolus vulgaris L.), 'Macarrão Favorito' variety, with indeterminate growth habit. Its seeds were germinated in pots and, after seedling establishment (about 7 days after sowing), thinning was performed to leave only two plants per pot. Irrigation was applied since the first day using water with the different levels of electrical conductivity, obtained by the addition of commercial iodate-free $\mathrm{NaCl}$ to the local supply water, and measured with a conductivity meter.

Irrigation treatments were applied through a drip system composed of a motor pump, disc filter, 25-mm-diameter polyethylene lines, and pressure-compensating drippers with nominal flow rate of $2.2 \mathrm{~L} \mathrm{~h}^{-1}$, installed along 0.005 -m-diameter, 0.35-m-long microtubes.

Irrigation management was based on the soil-water retention curve (Eq. 1) and water tension readings in tensiometers, to bring the soil back to field capacity.

$$
\theta=0.133+\left\{\frac{0.519-0.133}{\left[1+(0.032|\Psi|)^{1.575}\right]^{0.365}}\right\} \quad \mathrm{R}^{2}=0.992
$$

where:

$\theta \quad$ - actual volumetric moisture content, $\mathrm{cm}^{3} \mathrm{~cm}^{-3}$; and, $\Psi \quad$ - soil water potential, $\mathrm{kPa}$.

Table 1. Physical and chemical characteristics of the soil before fertilization

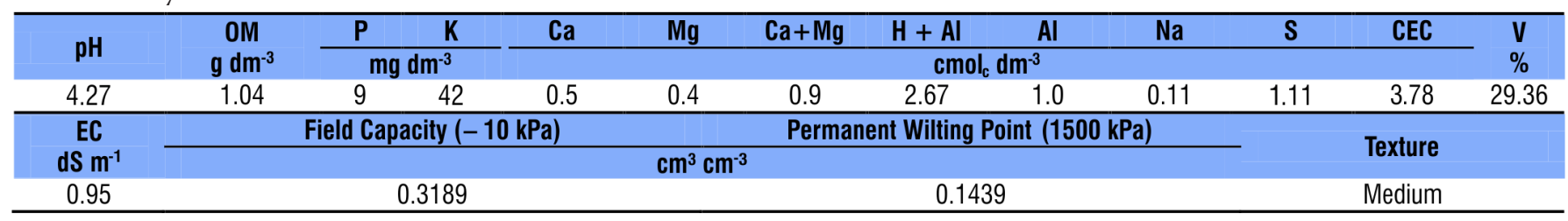


Tensiometers were installed at $0.15 \mathrm{~m}$ depth, close to the plant, in the central region of the pot, and water was replaced when the mean water tension in the soil was close to $20 \mathrm{kPa}$, allowing a reduction to $10 \mathrm{kPa}$ (tension adopted as field capacity). Pulse drip irrigation consisted in splitting the required volume into six irrigation pulses with 30 -min interval, whereas continuous irrigation consisted in applying the required water volume without interruption.

Pests and diseases were controlled by periodical sprayings using neem extract and copper fungicide.

For being a crop with indeterminate growth habit, green beans were harvested three times a week. After each harvest, the pods were removed and weighed. In the selection, pods that were curved, malformed (incidence of interocular cavity), unhealthy and with perforations caused by insects were considered as unfit for marketing. Number of marketable pods, marketable production and water use efficiency were evaluated.

Soil samples were collected at the beginning and end of the experiment to analyze the electrical conductivity of the soil saturation extract.

The data were subjected to analysis of variance and, in case of significance, regression analysis was carried out and means were compared by Tukey test at 0.05 probability level, using the statistical program Sisvar (Ferreira, 2008).

\section{Results AND Discussion}

The analysis of variance (Table 2) showed that there was interaction between water salinity and type of drip irrigation on the studied parameters.

Electrical conductivity in the soil saturation extract (ECse) and water consumption as a function of different levels of electrical conductivity of water (ECw) applied through continuous and pulse drip irrigation are presented in Table 3.

At the end of the experiment (79 days after sowing), there was an increase in soil salinity with the increase in irrigation
Table 2. Summary of analysis of variance (mean square) for mean production of pods per pot (PROD) and water use efficiency (WUE)

\begin{tabular}{lccc}
\hline \multicolumn{1}{c}{ SV } & DF & PROD & WUE \\
Drip system (D) & 1 & $208314.47^{\star \star}$ & $1061.59^{\star \star}$ \\
Salinity level (SL) & 4 & $847254.75^{\star \star}$ & $973.16^{\star \star}$ \\
D*SL $^{\star}$ Error & 4 & $18174.32^{\star *}$ & $50.04^{\star \star}$ \\
CV $(\%)$ & 40 & 2723.73 & 5.30 \\
\hline
\end{tabular}

* Significant, at 0.05 probability by $\mathrm{F}$ test; ${ }^{* \star}$ Significant at 0.01 probability by $\mathrm{F}$ test; $\mathrm{ns}$ : Not significant; CV - Coefficient of variation; SV - Source of variation; DF - Degrees of freedom

water salinity (Table 3). As irrigation water salinity increased, ECse varied from 1.26 to $7.64 \mathrm{dS} \mathrm{m}^{-1}$ for continuous drip irrigation and from 1.46 to $8.60 \mathrm{dS} \mathrm{m}^{-1}$ for pulse drip irrigation. Increase in ECse resulting from irrigation with water of different salinity levels was also observed in common bean by Santana et al. (2003).

Plant water consumption along the cycle decreased with the increment in the levels of irrigation water salinity, for both types of drip irrigation. There were reductions of $64 \%$ in the water consumption in plants irrigated by the continuous drip system and $48 \%$ in plants irrigated by the pulse drip system, due to the EC variation from 0.3 to $4.5 \mathrm{dS} \mathrm{m}^{-1}$ (Table 3).

The water volumes applied along the experiment are presented in Table 4. Larger volumes of water at all levels of electrical conductivity were applied in the continuous drip system, compared with the pulse drip system, in the initial stage.

Thus, it can be inferred that differences in ECse between the types of drip system can be justified by the fact that pulse drip irrigation maintains the soil moist for a longer period, so that the volume of saline water initially applied was smaller and, consequently, the amount of salts accumulated in the soil was also smaller, which delayed the deleterious effects of the salts and allowed for greater crop development.

Table 3. Electrical conductivity values in the soil saturation extract (ECse) and water consumption as a function of the type of drip irrigation and water salinity $(\mathrm{ECW})$ at the end of the experiment

\begin{tabular}{|c|c|c|c|c|c|}
\hline Drip irrigation & ECw & ECse & $\begin{array}{c}\text { Increase of ECse * } \\
(\%)\end{array}$ & $\begin{array}{l}\text { Water consumption } \\
\left(\mathrm{L} \mathrm{pot}^{-1}\right)\end{array}$ & $\begin{array}{l}\text { Reduction in water } \\
\text { consumption (\%) }\end{array}$ \\
\hline \multirow{5}{*}{ Continuous } & 0.3 & 1.26 & 32.63 & 32.18 & 0 \\
\hline & 1.5 & 3.38 & 255.79 & 18.32 & 43 \\
\hline & 2.5 & 4.95 & 421.05 & 17.06 & 47 \\
\hline & 3.5 & 5.57 & 486.32 & 13.88 & 57 \\
\hline & 4.5 & 7.64 & 704.21 & 11.70 & 64 \\
\hline \multirow{5}{*}{ Pulse } & 0.3 & 1.46 & 53.68 & 24.85 & 0 \\
\hline & 1.5 & 3.85 & 305.26 & 21.82 & 12 \\
\hline & 2.5 & 5.57 & 486.32 & 18.00 & 27 \\
\hline & 3.5 & 6.59 & 593.68 & 14.80 & 40 \\
\hline & 4.5 & 8.60 & 805.26 & 12.94 & 48 \\
\hline
\end{tabular}

*Initial value of electrical conductivity in the soil saturation extract: $0.95 \mathrm{dS} \mathrm{m} \mathrm{m}^{-1}$

Table 4. Water volumes periodically applied as a function of the type of drip system and water salinity

\begin{tabular}{crrrrrrrrrr}
\hline $\begin{array}{c}\text { Time } \\
\text { (days) }\end{array}$ & CDL1 & CDL2 & CDL3 & CDL4 & $\begin{array}{c}\text { CDL5 } \\
\left.\text { Aplied volume (L pot }{ }^{-1}\right)\end{array}$ & PDL1 & PDL2 & PDL3 & PDL4 & PDL5 \\
\hline $0-7$ & 1.4 & 1.4 & 1.4 & 1.4 & 1.4 & 1.4 & 1.4 & 1.4 & 1.4 \\
$8-31$ & 5.3 & 5.1 & 4.4 & 4.9 & 4.5 & 3.5 & 4.1 & 3.7 & 3.2 & 3.1 \\
$32-55$ & 13.7 & 8.3 & 8.5 & 6.8 & 4.8 & 11.1 & 7.7 & 7.0 & 6.6 & 5.7 \\
$56-79$ & 11.8 & 3.5 & 2.8 & 0.8 & 1.0 & 8.8 & 8.6 & 5.9 & 3.6 & 2.8 \\
Total & 32.2 & 18.3 & 17.1 & 13.9 & 11.7 & 24.8 & 21.8 & 18.0 & 14.8 & 13.0 \\
\hline
\end{tabular}

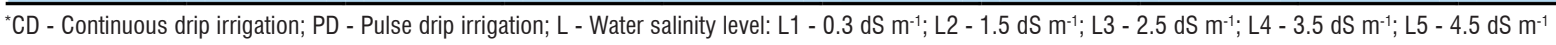


Ayers \& Westcot (1991) report that the presence of salts in the soil solution decreases the osmotic potential and retention forces, causing lack of water in the plant, i.e., the more saline the soil, the greater the energy spent by the plant to absorb water.

Similar behavior was observed by Santana et al. (2003), studying the effect of different salt concentrations in the irrigation water on common bean production. These authors found reductions of up to $69 \%$ in water consumption between plants subjected to 0.10 and $5.5 \mathrm{dS} \mathrm{m}^{-1}$. This result is consistent with the one observed for the continuous drip system but different from the one found for the pulse drip system, suggesting that this technique can be a beneficial alternative when saline water is used.

The effect of salinity on the production of pods per pot for each type of irrigation is presented in Figure 1A. The data fitted best to a decreasing linear equation, and the reduction due to the increase in irrigation water salinity was larger in plants under continuous drip irrigation. There were mean reductions of $181.11 \mathrm{~g} \mathrm{pot}^{-1}$ per unit increase in salinity for the continuous drip system and $147.83 \mathrm{~g} \mathrm{pot}^{-1}$ for the pulse drip system.

Reduction of production due to increase in salinity was also observed by Oliveira et al. (2015), working with cowpea

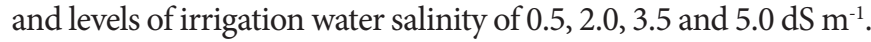
These authors demonstrated that salinity above $3.5 \mathrm{dS} \mathrm{m}^{-1}$ leads to significant loss in cowpea yield. In the present study, with green bean, the production decreased from $1.5 \mathrm{dS} \mathrm{m}^{-1}$.

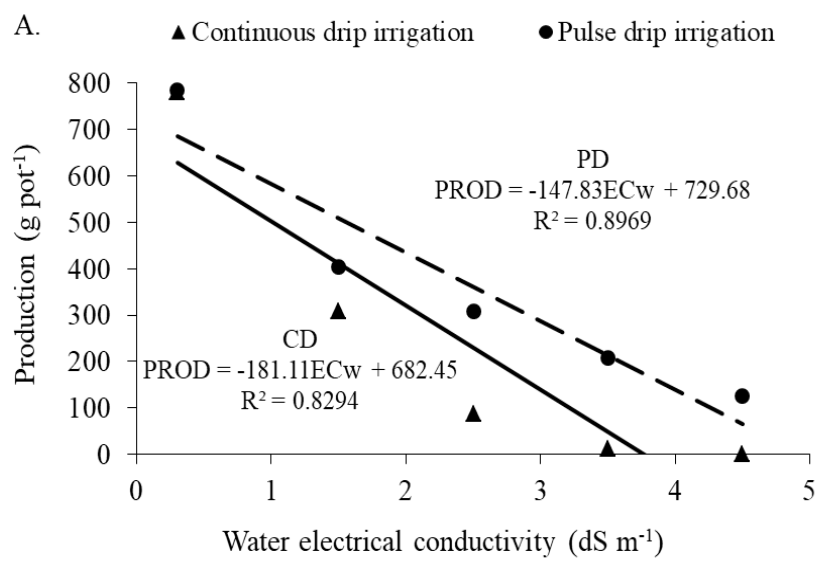

According to Silva et al. (2013), reduction in crop production is associated with the osmotic, toxic and nutritional processes of the saline stress, which affect the development of plant shoots, used for photosynthesis and total production of photoassimilates.

According to Figure $1 \mathrm{~B}$, there was no variation in production between the types of drip system at salinity of $0.3 \mathrm{dS} \mathrm{m}^{-1}$. This demonstrates that the use of pulse drip irrigation does not favor the increase in production. Conversely, the interaction between factors indicates greater advantage of using pulse drip irrigation when saline water is employed.

There was a reduction in production proportional to the decrease in water consumption by plants (Figure 2A), caused by the increase in soil salinity. The results confirm that the reduction in crop yield under saline conditions is caused by the reduction in water absorption by roots, resulting from the decrease in the osmotic potential and, consequently, in the total soil water potential, as reported by Mori et al. (2011) and Ajeel et al. (2015).

Better performance of green bean under pulse drip irrigation can be associated with the reduction in the volume of saline water applied in its initial development stage, which allowed for greater development due to the lower amount of salts accumulated in the soil. On the other hand, a larger volume of saline water was applied in the initial stage through continuous drip irrigation; thus, the effects of salinity occurred earlier on the plants.

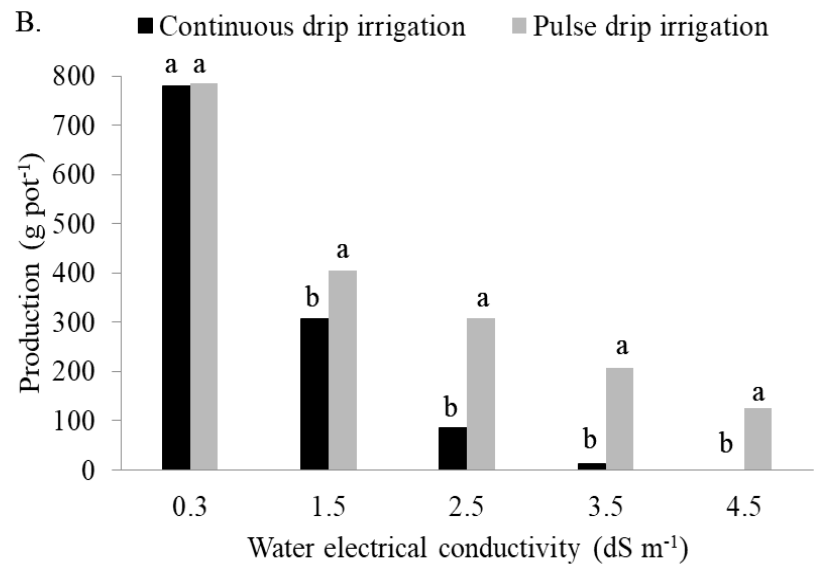

${ }^{*}$ Means followed by the same letter do not differ statistically at each salinity level by Tukey test at 0.05 probability level

Figure 1. Production of pods per pot as a function of irrigation water salinity and type of drip irrigation
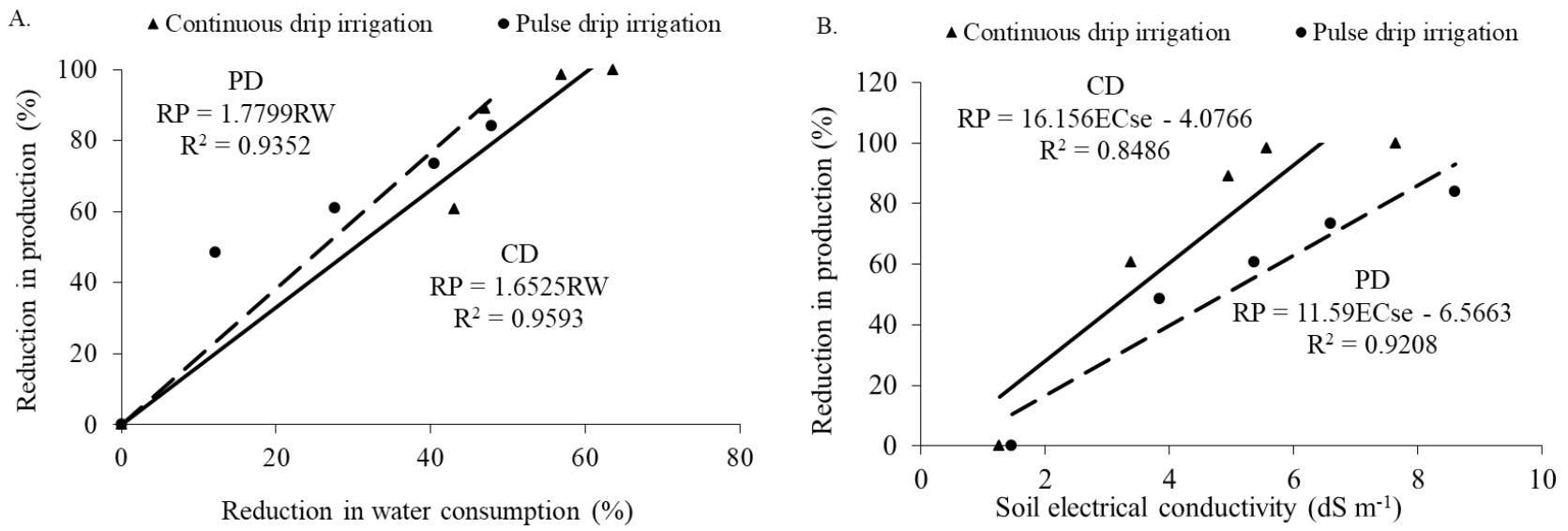

Figure 2. Reduction in green bean production (RP) as a function of the reduction in water consumption (RW) (A) and as a function of the salinity in soil saturation extract at the end of the crop cycle (B) for the different types of drip irrigation 

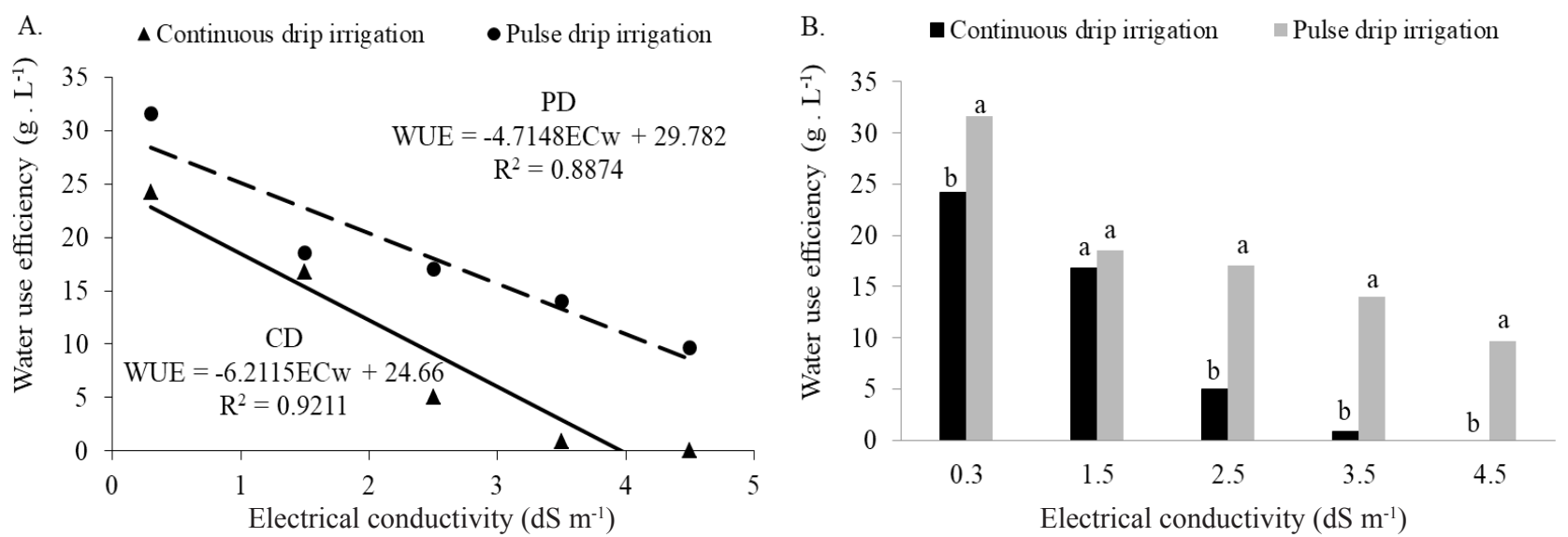

Figure 3. Water use efficiency (WUE) of green bean as a function of irrigation water salinity and type of drip irrigation

Ayers \& Westcot (1991) report reductions of 25, 50 and $100 \%$ in bean production for ECse levels of $2.3,3.6$ and $6.5 \mathrm{dS} \mathrm{m}^{-1}$, respectively. Figure $2 \mathrm{~B}$ presents the regression equations correlating the reduction in production with the electrical conductivity of the soil saturation extract (ECse). In the present study, ECse levels of 2.3, 3.6 and $6.5 \mathrm{dS} \mathrm{m}^{-1}$ led to reductions in production of 33,54 and $100 \%$ for continuous drip irrigation and of 20,35 and $69 \%$ for pulse drip irrigation, respectively. With the continuous drip irrigation, the results were close to those cited by Ayers \& Westcot (1991); however, the results were lower for the pulse drip system.

Reductions in green bean production close to $100 \%$ occurred when the electrical conductivity was approximately $6.44 \mathrm{dS} \mathrm{m}^{-1}$ in the continuous drip system and $9.19 \mathrm{dS} \mathrm{m}^{-1}$ in the pulse drip system (Figure 2B). As can be observed in Table 3 , comparing the water consumption at the lowest salinity level, pulse drip irrigation favored water saving.

Thus, the accumulation of salts in the soil, to the point of damaging the production, occurred later for the pulse drip irrigation than for continuous drip irrigation, allowing for greater plant development and higher water consumption at the final period of the crop cycle. As a result, higher EC was found in the saturation extract for the pulse drip irrigation with saline water. In the continuous drip system, due to the greater volume of saline water applied initially, salt concentrations deleterious to crop development were reached earlier.

Regarding water use efficiency (WUE), there was a linear reduction for both types of irrigation as water salinity increased, and this reduction was more accentuated for the continuous drip system. There were mean reductions in WUE of $25.19 \%$ in the continuous drip system and $15.83 \%$ in the pulse drip system per unit increase in salinity.

In Figures $3 \mathrm{~A}$ and $\mathrm{B}$, it is possible to observe the variation in WUE between the types of irrigation for the salinity level of $0.3 \mathrm{dS} \mathrm{m}^{-1}$. At this level, there was an increase of $22.9 \%$ in WUE when pulse drip irrigation was used $\left(31.44 \mathrm{~g} \mathrm{~L}^{-1}\right)$ compared with the continuous drip system $\left(24.24 \mathrm{~g} \mathrm{~L}^{-1}\right)$. This result corroborates the observations of Almeida et al. (2015) in the crisphead lettuce crop and Abdelraouf et al. (2012) in the potato crop.

\section{Conclusions}

1. The interaction between irrigation water salinity and type of drip irrigation was significant for all variables studied.
2. Irrigation water salinity negatively affected all variables analysed and was responsible for the increase in soil salinity levels.

3. Green bean production was affected by the reduction in its water consumption with the increasing levels of soil and water salinity.

4. Pulse drip irrigation reduced the negative effects of irrigation water salinity on green bean yield and increased water use efficiency.

\section{Literature Cited}

Abdelraouf, R. E.; Abou-Hussein, S. D.; Refaie, K.; El-Metwally, I. M. Effect of pulse irrigation on clogging emitters, application efficiency and water productivity of potato crop under organic agriculture conditions. Australian Journal of Basic and Applied Sciences, v.6, p.807-816, 2012.

Ajeel, A.; Saeed, A.; Dragonetti, G.; Comegna, A.; Lamaddalena, N.; Coppola, A. Effect of water salinity on the spatial variability of soil and plant parameters. Journal of Life Sciences, v.9, p.549-555, 2015. https://doi.org/10.17265/1934-7391/2015.11.007

Almeida, S. N. C.; Thiebaut, J. T. L.; Gravina, G. de A.; Araújo, L. C.; Daher, R. F. Avaliação de características morfológicas e agronômicas de linhagens de feijão-de-vagem em Bom Jesus do Itabapoana-RJ, com potencial de recomendação. Vértices, v.16, p.39-50, 2014.

Almeida, W. F. de; Lima, L. A.; Pereira, G. M. Drip pulses and soil mulching effect on american crisphead lettuce yield. Engenharia Agrícola, v.35, p.1009-1018, 2015. https://doi.org/10.1590/18094430-Eng.Agric.v35n6p1009-1018/2015

Ayers, R. S.; Westcot, D. W. A qualidade da água na agricultura. Campina Grande: UFPB, 1991. 218p.

Bottega, D. B.; Rodrigues, N. E. L.; Silva, A. G. da; Costa, E. N.; Boiça Júnior, A. L.; Resistência de genótipos de feijão-vagem ao ataque de Zabrotes subfasciatus (Bohemann, 1833) (Coleoptera: Chrysomelidae). Pesquisa Agropecuária Tropical, v.43, p.18-25, 2013. https://doi.org/10.1590/S1983-40632013000100014

Eid, A. R.; Bakry, A. B.; Taha, M. H. Effect of pulse drip irrigation and mulching systems on yield, quality traits and irrigation water use efficiency of soybean under sandy soil conditions. Agricultural Sciences, v.4, p.249-261, 2013. https://doi. org/10.4236/as.2013.45036 
Elnesr, M. N.; Alazba, A. A.; El-Abedein, A. I. Z.; El-Adl, M. M. Evaluating the effect of three water management techniques on tomato crop. Plos One, v.10, p.1-17.2015. https://doi.org/10.1371/ journal.pone.0129796

EMBRAPA - Empresa Brasileira de Pesquisa Agropecuária. Manual de métodos de análise de solo. 2.ed. Rio de Janeiro: Embrapa Solos, 1997. 212p.

Ferreira, D. F. Sisvar: Um programa para análises e ensino de estatística. Revista Científica Symposium, v.6, p.36-41, 2008.

Lima, C. A. de; Montenegro, A. A. de A.; Santos, T. E. M. dos; Andrade, E. M. de; Monteiro, A. L. N. Práticas agrícolas no cultivo da mandioca e suas relações com o escoamento superficial, perdas de solo e água. Revista Ciência Agronômica, v.46, p.697-706, 2015.

Mori, M.; Mola, I. di; Chiarandá, F. Q. Salt stress and transplant time in snap bean: Growth and productive behaviour. International Journal of Plant Production, v.5, p.49-64, 2011.

Nadal, R.; Guimarães, D. R.; Biasi, J.; Pinheiro, S. L. G.; Cardoso, V. T. M. Olericultura em Santa Catarina: Aspectos técnicos e econômicos. Florianópolis: EMPASC, 1986. 187p.

Oliveira, F. de A. de; Carrilo, M. J. S. de O.; Medeiros, J. F. de; Maracajá, P. B.; Oliveira, M. K. T. de. Desempenho de cultivares de alface submetidas a diferentes níveis de salinidade da água de irrigação. Revista Brasileira de Engenharia Agrícola e Ambiental, v.15, p.771777, 2011. https://doi.org/10.1590/S1415-43662011000800002
Oliveira, F. de A. de; Medeiros, J. F. de; Alves, R. de C.; Lima, L. A.; Santos, S. T. dos; Régis, L. R. de L. Produção de feijão caupi em função da salinidade e regulador de crescimento. Revista Brasileira de Engenharia Agrícola e Ambiental, v.19, p.10491056, 2015. https://doi.org/10.1590/1807-1929/agriambi. v19n11p1049-1056

Osman, H. S.; Salim, B. B. M. Influence of exogenous application of some phytoprotectants on growth, yield and pod quality of snap bean under $\mathrm{NaCl}$ salinity. Annals of Agricultural Science, v.61, p.1-13, 2016. https://doi.org/10.1016/j.aoas.2016.05.001

Santana, M. J. de; Carvalho, J. de A.; Silva, É. L. da; Miguel, D. da S. Efeito da irrigação com água salina em um solo cultivado com feijoeiro (Phaseolus vulgaris L.). Ciência e Agrotecnologia, v.27, p.443-450, 2003. https://doi.org/10.1590/S1413-70542003000200027

Silva, F. L. B. da; Lacerda, C. F. de; Neves, A. L. R.; Sousa, G. G. de; Sousa, C. H. C. de; Ferreira, F. J. Irrigação com águas salinas e uso de biofertilizante bovino nas trocas gasosas e produtividade de feijão-de-corda. Irriga, v.18, p.304-317, 2013. https://doi. org/10.15809/irriga.2013v18n2p304

Trani, P. E.; Passos, F. A.; Pereira, J. E.; Semis, J. B. Calagem e adubação do feijão-vagem, feijão-fava (ou fava-italiana), feijãode-lima e ervilha torta (ou ervilha-de-vagem). Campinas: IAC, 2015. 15p. 